http://dx.doi.org/10.18778/8088-839-5.06

Maciej Paszyn

Uniwersytet Łódzki

\title{
Polityka energetyczna Niemiec w latach 1990-2015. Próba bilansu 25-lecia
}

Celem niniejszego artykułu jest przybliżenie czytelnikowi problemu bezpieczeństwa energetycznego Niemiec w ostatnim ćwierćwieczu. Zmiany, do jakich doszło w niemieckim systemie energetycznym i w pojmowaniu bezpieczeństwa energetycznego w okresie po 1990 roku, pokazują, jak wiele zmieniło się w gospodarce światowej i europejskiej. Niemiecka energetyka oparta w roku 1990 i 2000 na węglu i atomie, w chwili obecnej po zmianach Energiewende wykorzystuje głównie gaz i dąży do zwiększenia udziału odnawialnych źródeł energii w ilości produkowanych megawatów.

W Niemczech w 2013 roku zużycie energii pierwotnej wyniosło 325,0 Mtoe, co oznacza, że w tym kraju występuje największe jej zużycie wśród krajów UE oraz jedno z największych na świecie (udział Niemiec w unijnej i światowej konsumpcji energii pierwotnej wynosi odpowiednio 19,4\% oraz $\left.2,6 \%^{1}\right)$. W latach 1965-2013 zużycie energii wzrosło o $26,9 \%$. Wiązało się to ze zmianami w strukturze źródeł energii pierwotnej dotyczącymi powolnego zwiększania udziału ropy naftowej, ograniczania udziału węgla kamiennego, wprowadzania gazu ziemnego i energii atomowej oraz upowszechniania innych niż hydroenergia odnawialnych źródeł energii (OZE). Struktura niemieckiego bilansu energetycznego jest $\mathrm{w}$ dużym stopniu zdywersyfikowana. Przejawem tego jest fakt, że ropa naftowa, węgiel i gaz ziemny mają po ponad 20\% udziału w strukturze źródeł energii pierwotnej (w 2013 roku odpowiednio $34,5 \%, 23,2 \%$ oraz $25,0 \%$ ). Oprócz tych źródeł znacznym udziałem charakteryzują się energia atomowa oraz OZE (w 2013 roku odpowiednio

1 Ministerstwo Gospodarki i Energii, Zahlen und Fakten Energiedaten, 01.10.2015, http://bmwi.de/DE/Themen/Energie/Energiedaten-und-analysen/Energiedaten/gesamtausgabe-,did=476134.html (dostęp: 16.07.2016). 
$6,8 \%$ oraz 9,1\%)². Utrzymywanie tej zdywersyfikowanej struktury źródeł energii pierwotnej znacząco zwiększa bezpieczeństwo energetyczne kraju, gdyż zmniejsza uzależnienie od poszczególnych źródeł energii oraz ogranicza potencjalny wpływ zawirowań na rynkach poszczególnych surowców energetycznych na niemiecki rynek energii. Gdy w maju 2011 roku, po awarii elektrowni atomowej w Fukushimie, podjęto decyzję o transformacji energetycznej RFN, okazało się, że ze względu na narzucone tempo zmian wprowadzona ma być nowa jakość w strategii energetycznej Niemiec. Głównymi jej założeniami są: rezygnacja z energii jądrowej do 2022 roku, rozwój odnawialnych źródeł energii (OZE), rozbudowa sieci przesyłowych, budowa nowych elektrowni konwencjonalnych i wzrost efektywności energetycznej. Strategia ma się opierać głównie na rozwoju odnawialnych źródeł energii ${ }^{3}$.

Jak podaje literatura przedmiotu, „Bezpieczeństwo energetyczne to stan gospodarki umożliwiający pokrycie bieżącego i perspektywicznego zapotrzebowania odbiorców na paliwa i energię w sposób technicznie i ekonomicznie uzasadniony, przy zachowaniu wymagań ochrony środowiska”. Jednocześnie bezpieczeństwo energetyczne jest częścią bezpieczeństwa narodowego, które obejmuje działania związane z pokryciem zapotrzebowania gospodarki na nośniki energii. Obejmuje ono następujące wymiary:

- surowcowo-produktowy - dotyczy głównie monitorowania i prognozowania potrzeb energetycznych państwa, z uwzględnieniem obecnych i przyszłych potrzeb oraz różnorodności, ilości i ceny nośników energii niezbędnych dla prawidłowego funkcjonowania i rozwoju gospodarki. Działania związane $\mathrm{z}$ tym wymiarem mają na celu zapewnienie dostaw poszczególnych nośników energii w ilościach adekwatnych do potrzeb, po możliwie niskich cenach;

- infrastrukturalny - obejmuje istnienie i prawidłowe funkcjonowanie instalacji koniecznych do zapewnienia ciągłości dostaw poszczególnych nośników energii. Obejmuje on poszerzanie i odtwarzanie infrastruktury przez realizację nowych inwestycji oraz remontowanie istniejących instalacji;

- polityczny - obejmuje działania państwa w obszarze kontroli właścicielskiej, regulacji prawnych działań gospodarczych, w tym zezwoleń i koncesji, oraz polityki fiskalnej i budżetu państwa ${ }^{4}$;

2 BP Stattistic 2014.

3 A. Lewandowski, K. Żmijewski, Wymiary energetycznego bezpieczeństwa, „Energetyka Cieplna i Zawodowa” 2007, nr 5.

4 W ramach wymiaru politycznego można wyróżnić także zarządzanie kryzysowe. Zarządzanie kryzysowe obejmuje identyfikowanie zagrożeń i opracowanie sposobów 
- międzynarodowy - to powiązania w polityce międzynarodowej państwa, w których znaczenie mają kwestie przypisane pozostałym wymiarom bezpieczeństwa energetycznego. W ramach tego wymiaru rozpatruje się konieczność importu nośników energii i sposoby jego realizacji, zobowiązania wynikające z porozumień międzynarodowych. Bardzo ważną częścią wymiaru międzynarodowego jest ocena skutków, jakie w sprawach zagranicznych wywołują działania podejmowane w ramach bezpieczeństwa energetycznego.

Bezpieczeństwo energetyczne ma zapewnić:

1. Niezawodność dostaw - zapewnienie stabilnych warunków, umożliwiających pokrycie bieżącego i perspektywicznego zapotrzebowania gospodarki i społeczeństwa na energię odpowiedniego rodzaju i wymaganej jakości, realizowanych poprzez dywersyfikację kierunków dostaw oraz rodzajów nośników energii pozwalającej na ich wzajemną substytucję;

2. Konkurencyjność - oznacza tworzenie dla wszystkich uczestników rynku energii jednakowych warunków działalności, w szczególności: stworzenie warunków zapewniających wiarygodność oraz przejrzystość cen i kosztów (punkt odniesienia dla producentów i użytkowników energii), eliminację wykorzystywania systemu kreowania cen dla realizacji polityki socjalnej lub jako instrumentu ekonomicznego wspierania określonego nośnika energii;

3. Spełnienie wymogów ochrony środowiska - minimalizację negatywnego oddziaływania sektora energii na środowisko i warunki życia społeczeństwa ${ }^{5}$.

Dla Niemiec bezpieczeństwo energetyczne oznaczało konieczność wprowadzenia rozwiązań instytucjonalno-prawnych oraz zmian strategii energetycznej państwa. Musiano brać pod uwagę uwarunkowania geopolityczne, ponadto musiano zachować istotę federacyjnej struktury państwa i nie zawsze zbieżnych interesów poszczególnych landów. Czołowe miejsce w strukturze wytwarzania energii elektrycznej zajmują paliwa kopalne, których udział w rynku produkcji wynosi $80 \%$. Na drugiej pozycji znalazła się energetyka niekonwencjonalna, w literaturze przedmiotu znana jako OZE (odnawialne

reagowania na wypadek ich wystąpienia zarówno w postaci odpowiednich narzędzi prawnych, jak i utrzymywania zdolności służb państwowych do reagowania na różne rodzaje sytuacji kryzysowych. Sytuacje takie mogą obejmować skażenie środowiska czy zagrożenie terrorystyczne.

5 D. Steivan, Energiepolitik. Wissenschaftliche und wirtschaftliche Grundlagen, Zürich 2007, s. 38. 
źródła energii). Jej udział w rynku to około $12-13 \%$. Z kolei udział energii jądrowej w bilansie energetycznym kraju szacuje się na mniej niż $8 \%{ }^{6}$.

Przed rozpoczęciem przemian sektora energetycznego, na początku XXI wieku, w Niemczech istniało trzech regionalnych monopolistów. Przyjęcie przez rząd federalny ustawy o gospodarce energetycznej w dniu 28 kwietnia 1998 roku było początkiem zmian, jakie nastąpiły na rynku energii u naszych zachodnich sąsiadów. W dodatku, w tym samym czasie miało miejsce całkowite uwolnienie rynku energii bez zachowania okresów przejściowych. Obecna struktura niemieckiego rynku energetycznego jest taka sama jak przed reformą. Nadal funkcjonują tam pionowo zintegrowane firmy o dominującej pozycji na rynku. Warto nadmienić, że obok trzech istniejących przedsiębiorstw energetycznych (E.ON, RWE, EnBW) w 2002 roku pojawił się kolejny znaczący podmiot - Vattenfall Europe, powstały w wyniku połączenia spółek: Bewag, H EW, Laubag i VEA.

Udział energetyki jądrowej w bilansie energetycznym Republiki Federalnej Niemiec sięga drugiej połowy lat 50., kiedy zbudowano kilka reaktorów eksperymentalnych ${ }^{7}$. Pierwszy reaktor komercyjny oddano do użytku w 1969 roku. W 1975 roku uruchomiono pierwszy reaktor w EJ Biblis (Biblis A, typ PWR), który jest najstarszym blokiem jądrowym ze wszystkich siedemnastu pracujących do dziś. Ostatnie bloki podłączono do sieci w latach 1988-1989. Co ważne, NRD nie pozostawała w tyle. W 1966 roku uruchomiona została $\mathrm{w}$ Rheinsberg (Brandenburgia) prototypowa elektrownia na bazie projektu radzieckiego o mocy 62-72 MWe. W 1974 roku rozpoczął pracę pierwszy reaktor w elektrowni Greifswald/Lubmin o mocy 408 MWe. W NRD, do końca 1990 roku pracowało 6 reaktorów energetycznych, a w budowie i planach było 7 kolejnych. Co istotne dla dalszej narracji, RFN była, obok Stanów Zjednoczonych, Francji i Japonii, światowym potentatem w rozwoju technologii jądrowych. Na podstawie licencji amerykańskich Niemcy opracowali własne konstrukcje reaktorów ${ }^{8}$.

6 A. Lewandowski, M. Kaliski, P. Frączek, Rozwój energetyki jądrowej a bezpieczeństwo energetyczne, „Rynek Energii” 2012, nr 2.

7 W 1960 roku został uruchomiony pierwszy reaktor energetyczny (w Kahl, typ BWR, moc $16 \mathrm{MWe}$ ), wybudowany w ciągu zaledwie dwóch lat. Ł. Kuźniarski, Energetyka jadrowa w Niemczech, CSM, Warszawa 2011, s. 3.

$8 \quad$ PWR (Pressurised Water Reactor - reaktor wodno-ciśnieniowy) i BWR (Boiling Water Reactor - reaktor wodny wrzący). Ponadto niemieckie ośrodki naukowe prowadziły zaawansowane prace nad nowymi technologiami: HTGR (High Temperature Gascooled Reactor - reaktor wysokotemperaturowy chłodzony gazem) i FBR (Fast Breeder 
Ponadto niemieccy specjaliści badali możliwości wykorzystywania toru jako paliwa jądrowego - zamiast uranu (światowe zasoby toru są 3-4 razy większe niż zasoby uranu). Niemiecki przemysł jądrowy był jednym ze światowych liderów9. Pomimo zmian, do jakich doszło w ostatniej dekadzie, w RFN do dziś pracują różne zakłady cyklu paliwowego, świadczące usługi dla firm z całego świata, $\mathrm{w}$ tym m.in. zakłady wzbogacania uranu metodą wirówkową w Gronau (Nadrenia Północna-Westfalia) oraz zakłady produkcji paliwa jądrowego w Lingen (Dolna Saksonia). Ponadto w Ellweiler (Nadrenia-Palatynat) pracowała w latach 1960-1989 kopalnia uranu ${ }^{10}$. Ważnym elementem funkcjonowania niemieckiej energetyki jądrowej był opór części społeczeństwa wobec tej gałęzi przemysłu. Niemiecką cywilną energetykę jądrową, powszechnie, choć mylnie utożsamiano z zimnowojennym zagrożeniem atomowym, groźbą globalnej wojny jądrowej ${ }^{11}$. Protesty nasiliły się po awarii $\mathrm{w}$ amerykańskiej elektrowni Three Mile Island w USA (Harrisburg, stan Pensylwania) marcu w 1979 roku. Awaria w Czarnobylu (ZSRR, dziś teren Ukrainy) w kwietniu 1986 roku spowodowała nasilenie fali protestów i praktycznie przekreśliła plany budowy kolejnych reaktorów ${ }^{12}$. W atmosferze protestów antyatomowych Federalny Sąd Administracyjny RFN w roku 1988, nakazał wyłączyć i rozebrać elektrownię Muelheim-Karlich (1x PWR, 1219 Mwe), po przepracowaniu zaledwie roku. Niechęć społeczeństwa niemieckiego do energetyki jądrowej wydaje się zrozumiała, gdyż media regularnie informują o „awariach” w elektrowniach atomowych. Doniesienia te są prawie zawsze przesadzone. Wszystkie „awarie” jakie miały miejsce w niemieckich elektrowniach jądrowych po 1990 roku były drobnymi usterkami, które nie miały żadnego wpływu na bezpieczeństwo elektrowni ani na bezpieczeństwo ludności mieszkającej blisko elektrowni ${ }^{13}$.

Reactor - reaktor powielający na prędkich neutronach). Environment and Energy. Electricity Statistics - Provisional data for 2009, Eurostat, 2010 edition, s. 3.

9 Firma Siemens/KWU eksportowała swoje elektrownie m.in. do Brazylii, Argentyny i Iranu. Ł. Kuźniarski, dz. cyt., s. 6. Por: T. Leszczyński, Energetyka jądrowa w państwach Unii Europejskiej, „Biuletyn Urzędu Regulacji Energetyki” 2008, nr 5.

10 Podobne kopalnie pracowały na terenie NRD w Saksonii w latach 1946-1989. Uran wydobywany w NRD został wykorzystany w radzieckim programie zbrojeń jądrowych.

11 Już w 1975 roku w Wyhl (Badenia-Wirtembergia) wobec protestów inwestor odstąpił od budowy i sprzedał zamówione urządzenia do elektrowni Philippsburg.

12 W tym czasie prężnie działała już partia Zielonych, która w 1983 roku zdobyła swoje pierwsze miejsca w Bundestagu i zaczęła domagać się likwidacji energetyki jądrowej w RFN. Odejście od energetyki jądrowej pojawiło się w programie SPD, która postanowiła „zagospodarować” elektorat antyatomowy.

13 Tylko 39\% Niemców uważa, że doniesienia medialne nt. awarii są przesadzone, 53\% uważa że wręcz przeciwnie. Tymczasem, jak wskazuje statystyka, niemieckie 
Aż 69\% Niemców uważało że elektrownie są niedostatecznie zabezpieczone przed atakami terrorystycznymi, przeciwnego zdania jest $23 \%$. Prawie połowa Niemców (45\%) nie ufała i nadal nie ufa dozorowi jądrowemu. Dzieje się tak, mimo że w ciągu ostatnich 25 lat władze starają się uspokoić obywateli ${ }^{14}$. Przez całe lata 90. obowiązywało nieformalne moratorium na budowę nowych reaktorów. W 1999 roku rząd federalny nałożył na operatorów i właścicieli elektrowni atomowych, specjalne zobowiązanie finansowe z tytułu „zabezpieczenia funduszy na zagospodarowanie odpadów promieniotwórczych, demontaż elektrowni oraz rekultywację zamkniętych kopalń węgla brunatnego"15.

Następnie, w 2001 roku koalicja SPD-Zieloni przeforsowała nowelizację ustawy o energii atomowej (Atomgesetz - AtG). Przewidywała ona stopniową likwidację elektrowni atomowych. Istotą nowelizacji był załącznik, który nałożył limity produkcji energii elektrycznej dla każdego z pracujących ówcześnie 19 reaktorów w taki sposób, że w praktyce skracało to okres eksploatacji każdego reaktora do 32 lat ${ }^{16}$. Łącznie wszystkie bloki jądrowe nie mogły wytworzyć więcej niż 2623 TWh energii elektrycznej (jeden blok o mocy 1000 MWe wytwarza rocznie 8 TWh energii). Na podstawie ww. załącznika utworzono terminarz zamykania poszczególnych bloków elektrowni. Ostatni blok - Neckarwestheim-2 - miał być zamknięty w 2022 roku. Strona rządowa groziła podjęciem samowolnej decyzji o natychmiastowej likwidacji elektrowni bez jakiejkolwiek rekompensaty dla właścicieli, jeśli nie zgodzą się na dobrowolne wyłączenia ${ }^{17}$. $\mathrm{Z}$ kolei firmom energetycznym udało się

elektrownie należą do najbezpieczniejszych na świecie. 51\% Niemców uważa, że możliwa jest bezpieczna eksploatacja EJ, 44\% uważa, że nie.

Przykładem były zmiany w energetyce na terenie b. NRD. W chwili jednoczenia Niemiec w 1990 r. wyłączono wszystkie 5 pracujących reaktorów w elektrowni w Greifswaldzie.

15 Wysokość zobowiązań władze ustaliły na poziomie 50 mld marek, jednak ostatecznie zmniejszono kwotę do $25 \mathrm{mld}$.

16 A. Rubinowicz, Atom do lamusa, „Gazeta Wyborcza” 2001, nr 136, s. 22. Każdy reaktor był zaprojektowany na 40 lat eksploatacji, ponadto możliwe jest bezpieczne wydłużenie tego okresu do 60 lat.

17 W zamian za zgodę na likwidację elektrowni, operatorzy uzyskali gwarancję, że w przyszłości nie zapadną jednostronne decyzje rządu federalnego skutkujące skróceniem terminów eksploatacji reaktorów. Firmy musiały zadbać o wybudowanie dwóch składowisk odpadów promieniotwórczych oraz wypalonego paliwa w miejscowościach Ahaus (Nadrenia Północna-Westfalia) i Gorleben (Dolna Saksonia). Rząd zobowiązał się nie podnosić krajowych standardów bezpieczeństwa obiektów jądrowych oraz nie wywierać na właścicielach i operatorach elektrowni presji ekonomicznej i podatkowej, tak jak zrobił to w 1999 roku. 
wynegocjować przepis zezwalający na przenoszenie kwot produkcji energii między poszczególnymi reaktorami.

Wydawało się, że wygrana chadeków w 2005 roku zmieni nastawienie do energetyki jądrowej. W 2008 roku Angela Merkel zaczęła mówić o rewizji polityki energetycznej ${ }^{18}$. Kierownictwa obu chadeckich ugrupowań opowiedziały się za zatrzymaniem likwidacji energetyki jądrowej. Na początku lipca 2008 roku przewodniczący Komisji Europejskiej, Jose Manuel Barroso, otwarcie poparł stanowisko pani kanclerz ${ }^{19}$. Jednocześnie SPD twardo upierała się przy swoim stanowisku ${ }^{20}$. W tym czasie operatorzy próbowali ratować trzy najstarsze bloki, których wyłączenie miałoby nastąpić w 2009 roku $^{21}$. Władze umożliwiły operatorom odsunięcie ustawowego terminu zamknięcia bloków aż do momentu uchwalenia przez nowy rząd CDU/CSU-FDP nowego terminarza, który dał dodatkowe 8 lat dla każdego z tych najstarszych bloków. Pod koniec października 2009 roku CDU/CSU i FDP podpisały umowę koalicyjną, której dwa punkty dotyczyły energii atomowej: jeden wydłużenia eksploatacji EJ, a drugi budowy ostatecznego składowiska wypalonego paliwa jądrowego w Gorleben. Stanowiska ministrów związanych z energetyką jądrową (BMU, BMWI, BBF) objęli ludzie o pragmatycznym nastawieniu - Norbert Röttgen, Reiner Brüderle i Annette Schavan ${ }^{22}$.

189 czerwca 2008 roku, po spotkaniu władz CDU i CSU w Erding w Bawarii stwierdziła, że „decyzja o wycofaniu się RFN z energetyki jądrowej była błędem”. Następnie, 18 czerwca 2008, w Berlinie powiedziała, że „nie ma sensu wyłączenie w ciągu 12 lat wszystkich elektrowni atomowych, by potem kupować prąd z takich elektrowni w Czechach, we Francji czy Finlandii”.

19 KE od lat popiera energetykę jądrową w UE, chociaż ostateczne decyzje co do jej wprowadzenia lub utrzymania nadal zostawia państwom członkowskim.

207 lipca 2008 r. kierownictwo tej partii opowiedziało się za wprowadzeniem do konstytucji zakazu budowania nowych elektrowni atomowych.

21 Były to reaktory Neckarwestheim-1, Brunsbüttel i Biblis A, co częściowo się udało. Co prawda rząd federalny odmówił w 2009 roku firmie RWE pozwolenia na przesunięcie części niewykorzystanej kwoty z zamkniętej elektrowni Mülheim-Kärlich, jednak RWE porozumiała się z firmą E.On w sprawie sprzedaży kwoty, która pozostała po wyłączonej przedwcześnie (2003 r.) elektrowni Stade (należącej do E.On). Kwota ta $(4,8 \mathrm{TWh}$ energii elektrycznej, pół roku pracy na pełnej mocy) zasiliła blok Biblis A. Wartość sprzedaży pozostaje tajemnicą handlową obu firm. Oba bloki elektrowni Biblis prawie nie pracowały w 2009 roku pod pretekstem długiej modernizacji, ale powszechnie wiadomo, że operatorowi chodziło przede wszystkim o zaoszczędzenie części pozostałych kwot. Równocześnie Vattenfall wydłużył postój elektrowni Krümmel i Brunsbüttel, aby dać im dodatkowy rok pracy.

22 A. Rubinowicz, $d z$. cyt. 
We wrześniu 2010 roku kanclerz Merkel ogłosiła decyzję rządu federalnego, w której przedłużono pozwolenia na eksploatację o 8 lat reaktorów uruchomionych przed 1980 rokiem oraz o 14 lat reaktorów uruchomionych od 1980 roku - w stosunku do dat przewidzianych w załączniku do ustawy o energii atomowej z 2002 roku $^{23}$. W zamian operatorzy zostali obłożeni kolejnymi podatkami. Pierwszy z nich dotyczy opłat od każdego grama paliwa jądrowego $\mathrm{o}^{24}$. Drugi podatek to stała opłata na rzecz wsparcia rozwoju Odnawialnych Źródeł Energiii ${ }^{25}$. Trzeci podatek to nowy „podatek ekologiczny”, płacony od każdego pracującego reaktora aż do momentu jego wyłączenia. Łącznie wynieść miał 15 mld euro od wszystkich elektrowni przez cały przewidywany okres ich eksploatacji. Tanie źródła energii elektrycznej, jakimi są elektrownie atomowe, pozwalały gospodarce niemieckiej utrzymać konkurencyjność wobec pozostałych gospodarek narodowych Unii Europejskiej ${ }^{26}$.

Według OECD koszt $1 \mathrm{MWh}$ prądu z energetyki jądrowej w Niemczech wynosi 49,97 a z wiatraków już 105,81\$. Podatnicy i właściciele firm płacą znaczące kwoty na funkcjonowanie sektora Odnawialnych Źródeł Energii ${ }^{27}$. Pomimo faktycznej likwidacji energetyki jądrowej w RFN, niemiecki przemysł atomowy nadal istnieje. Niemieckie reaktory do dziś pracują bardzo efektywnie w Finlandii, Czechach, Bułgarii oraz na Słowacji i Węgrzech, spełniając wszystkie wymogi bezpieczeństwa Unii Europejskiej. W 1999 roku rozpoczęła się, trwająca dekadę, współpraca Siemensa, RWE, E.On i EnBW z francuską Arevą, której efektem są dwa reaktory oferowane dziś na światowym rynku

23 Niemiecki Bundestag przyjął 28 października 2010 roku nowelizację ustawy o energetyce atomowej, zakładającą wydłużenie okresu eksploatacji niemieckich reaktorów jądrowych o średnio 12 lat.

24 Wynosił 145 euro od każdego grama dwutlenku uranu - $\mathrm{UO}_{2}$. Łącznie to 2,3 mld euro rocznie od wszystkich operatorów. Podatek miał obowiązywać przez 6 lat.

25 W latach 2011-2012 wynosić miała 300 mln euro rocznie, w latach 2013-2016 200 mln euro rocznie, a następnie zastąpić ją miał podatek w wysokości 9 euro od każdej wyprodukowanej MWh energii elektrycznej, z którego cały dochód będzie przeznaczany na subsydia dla właścicieli farm wiatrowych.

26 Ciekawa jest analiza wpływu przedłużenia okresu eksploatacji atomu na ceny energii elektrycznej wykonana w styczniu 2010 r. przez firmy konsultingowe r2b energy consulting oraz EEFA (specjalizujące się w analizach sektora energetycznego) na zlecenie Bundesverband der Deutschen Industrie e.V. (BDI) wykazała, że wydłużenie okresu eksploatacji wszystkich pracujących bloków jądrowych do 60 lat spowoduje zachowanie w 2030 r. o 16\% niższych cen energii dla gospodarstw domowych.

27 Tylko w 2008 roku podatnicy dofinansowali OZE kwotą 5 mld euro. Za takie pieniądze można zbudować nowy blok jądrowy o mocy 1600 MWe lub bloki węglowe o mocy 2700 MWe. 
- EPR i Kerena. Na skutek sporu z Francuzami, Siemens wycofał się z konsorcjum z Arevą w 2009 roku i rozpoczął współpracę z rosyjskim Atomstrojeksportem. Z kolei RWE i E.On utworzyły spółkę Horizon Nuclear Power, która planuje postawić kilka dużych reaktorów na terenie Wielkiej Brytanii (łącznie o mocy $6000 \mathrm{MWe})$. Ponadto RWE była zainteresowana również bułgarską budową nowej elektrowni Belene i w 2009 roku próbowała przejąć holenderską elektrownię Borssele. Natomiast E. On jest członkiem konsorcjum Fennovoima, które planuje budowę nowej elektrowni jądrowej w Finlandii ${ }^{28}$.

Powojenny rozwój przemysłu ciężkiego w RFN był związany z wydobyciem węgla kamiennego w Nadrenii Północnej-Westfalii oraz w Zagłębiu Saary. To on napędzał zachodnioniemiecki przemys ${ }^{29}$. Jednak, od lat 80 ., węgiel kamienny stracił na konkurencyjności. W roku 2000 węgiel kamienny i brunatny miały udział w produkcji 50,5\% energii elektrycznej. W roku 2013 było to $45,1 \%$. W XXI wieku z 83 mld ton zalegających pod ziemią, za wydobywalne uważa się $36 \mathrm{mld}$. Jego pokłady znajdują się w głębokich, trudnych do eksploatacji formacjach geologicznych, z których wydobycie się nie opła$\mathrm{ca}^{30}$. Obecnie węgiel kamienny wydobywany jest w pięciu kopalniach położonych w Zagłębiu Ruhry i Saary oraz w Ibbenbüren. Aktualnie wydobywa się $14,5 \mathrm{mln}$ ton rocznie. W Niemczech według planów rządowych do 2018 roku zostanie wstrzymane wydobycie węgla kamiennego, a kontynuowane będzie wydobycie węgla brunatnego. Po planowanym zaprzestaniu wydobycia węgla kamiennego z własnych złóż wzrośnie zależność Niemiec od importu surowców energetycznych. Aby zaspokoić krajowy popyt, niezbędny jest import tego paliwa, którego głównymi dostawcami są: Rosja, Kolumbia oraz Polska. W roku 2013 wydobycie węgla kamiennego w Niemczech stanowiło 5\% produkcji z roku 1956. Sektor wydobywczy to wciąż 14500 miejsc pracy ${ }^{31}$. Rząd federalny w 2014 roku zasilił kopalnie węgla kamiennego kwotą 1,65 mld euro dotacji. Subsydia ustaną w roku 2018. Jak już wspomniano niewielki procent węgla kamiennego spalanego $w$ niemieckich elektrowniach pochodzi z lokalnych kopalńn ${ }^{32}$. W roku 2013 import węgla kamiennego wzrósł

28 Ł. Kuźniarski, dz. cyt., s. 16.

29 W latach sześćdziesiątych ubiegłego stulecia wydobycie utrzymywało się na poziomie $150 \mathrm{mln}$ ton rocznie.

30 Według danych niemieckich średni koszt wydobycia 1 tony węgla kamiennego w Niemczech wynosi 180 euro, natomiast średnia cena importowanego węgla w 2013 roku wyniosła 79 euro za tonę.

31 W regionie Nadrenii Północnej-Westfalii działają jeszcze trzy kopalnie.

32 Węgiel używany w niemieckich elektrowniach jest importowany z Rosji (29,3\%), Kolumbii (21,2\%), Stanów Zjednoczonych (20,3\%), Australii, RPA i Polski. 
o 15,2\% w stosunku do roku 2012. W 2007 roku rząd Niemiec zatwierdził plan zamknięcia wszystkich kopalni węgla kamiennego do 2018 roku. Wynika to $\mathrm{z}$ faktu, że jest to branża deficytowa, której utrzymanie kosztuje skarb państwa 2,5 mld euro rocznie.

Inaczej wygląda udział węgla brunatnego w strukturze wydobycia i zużycia paliw w niemieckiej gospodarce. Niemcy produkują go najwięcej na świecie, wyprzedzając Australię, Rosję i Stany Zjednoczone. W działających lub planowanych odkrywkach zalega 5,6 mld ton węgla brunatnego - całkowite rezerwy wydobywalnego węgla brunatnego wynoszą 34,8 mld ton. W przeciwieństwie do kopalń węgla kamiennego, odkrywki węgla brunatnego i dziś przynoszą zyski. W roku $2013 \mathrm{w}$ całych Niemczech pozyskano 182,7 mln ton - w stosunku do 169,8 mld ton w roku 2009. W roku 2013 w niemieckim sektorze wydobycia węgla brunatnego pracowało 16410 osób. W czterech niemieckich regionach wydobywczych kopalnie i/lub elektrownie posiadają koncerny RWE, Vattenfall, E.ON i MIBRAG ${ }^{33}$.

Według Federalnej Agencji ds. Sieci w latach 1990-2010 uruchomiono w Niemczech bloki w elektrowniach na węgiel brunatny i kamienny o łącznej mocy 9,3 gigawatów $(G W)^{34}$. Jednocześnie wygaszono bloki o łącznej mocy niemal $25 \mathrm{GW}$ (15,8 GW w elektrowniach opalanych węglem brunatnym i 8,3 GW w elektrowniach pracujących na węglu kamiennym. To naturalne z punktu widzenia technicznego i ekonomicznego działanie, po roku 2011 nie było kontynuowane. W zamierzeniach władz wygaszaniu elektrowni węglowych towarzyszyć miało powstawanie elektrowni opartych na gazie, głównie z Rosji, i na OZE. Po roku 2011 do sieci przyłączono elektrownie węglowe o łącznej mocy 6,7 GW. Jednocześnie z użytku wycofano 3,8 GW $\mathrm{GW}^{35}$. Jako że proces planowania i budowy elektrowni węglowej trwa co najmniej 3 lata, moce uruchomione po roku 2011 zostały zaplanowane jeszcze przed katastrofą w Fukushimie.

Zgodnie ze stanem na rok 2014, w Niemczech nie powstaje żadna elektrownia opalana węglem brunatnym. W budowie są za to bloki opalane węglem

33 W czerwcu 2014 roku rząd Brandenburgii - drugiego co do wielkości obszaru wydobycia węgla brunatnego - przedłużył Vattenfallowi koncesję na eksploatację zasobów w rejonie Welzow-Süd na okres po roku 2026.

34 Po roku 1990 ograniczono inwestycje w elektrownie węglowe w Niemczech Zachodnich, przesuwając środki na modernizację przestarzałych elektrowni na wschodzie kraju. Z tego względu elektrownie na wschodzie mają dłuższy oczekiwany czas pracy niż te na zachodzie.

35 A. Ancygier, Niemiecka polityka energetyczna: dwa kroki naprzód, jeden krok w tyt, Warszawa 2014. 
kamiennym o łącznej mocy 4,3 GW. W najbliższych czterech latach planuje się wygasić bloki o mocy $4 \mathrm{GW}^{36}$. Związek BDEW zastrzega jednak, że planowane elektrownie mogą wcale nie powstać, jako że warunki, tak polityczne, jak i rynkowe, nie sprzyjają elektrowniom na gaz ani na węgiel kamienny ${ }^{37}$.

RFN jest jednym $\mathrm{z}$ najważniejszych na świecie promotorów polityki ochrony klimatu i odnawialnych źródeł energii (OZE). Taką postawę wymusza na rządzie niemiecka opinia publiczna, wyczulona na kwestie ochrony środowiska ${ }^{38}$. To Niemcy były inicjatorem opracowania unijnej polityki ochrony klimatu, a w trakcie niemieckiej prezydencji w UE kanclerz Angela Merkel doprowadziła do przyjęcia przez przywódców UE w marcu 2007 planu $3 \times 20 \%$, tj. redukcji emisji $\mathrm{CO}_{2}$ o $20 \%$, zwiększenia udziału OZE w bilansie energetycznym do $20 \%$ i zmniejszenia zużycia energii o $20 \%$ do 2020 roku. Wspierany przez państwo stopniowy rozwój odnawialnych źródeł energii w Niemczech rozpoczął się w 2000 roku, po uchwaleniu pierwszej ustawy o OZE. Udział odnawialnych źródeł w zaopatrzeniu w energię wzrósł w ciągu ostatnich dziesięciu lat o prawie 20 punktów procentowych, do poziomu ok. 28\% w 2014 roku. Przyjęte przez koalicję SPD-Zieloni cele były bardzo ambitne. Zostały określone jako „korytarze rozwoju” OZE, które wskazywać miały minimalny i maksymalny cel rozbudowy odnawialnych źródeł w danym roku. W 2050 roku udział OZE w zapotrzebowaniu na energię elektryczną ma wynieść aż $80 \%$. Zakładane tempo rozwoju OZE ma pomóc Niemcom w realizacji celów Energiewende. Jednocześnie udział odnawialnych źródeł energii $\mathrm{w}$ produkcji energii elektrycznej $\mathrm{w}$ Niemczech wzrasta $\mathrm{z}$ roku na rok. W 2014 roku energia elektryczna wyprodukowana przez OZE stanowiła $26,2 \%$ całkowitej produkcji i był to drugi co do wielkości udział w produkcji energii. Wiodącą rolę $\mathrm{w}$ dalszym ciągu odgrywają węgiel brunatny

36 Według danych Zrzeszenia Importerów Węgla, tylko w pierwszym kwartale $2014 \mathrm{r}$. produkcja energii elektrycznej z elektrowni opalanych węglem kamiennym wzrosła o 7,5\%. Import węgla na potrzeby elektrowni wzrósł o 25\% do $10 \mathrm{mln}$ ton. Dane za: R. Bajczuk, Gaz przegrywa z weglem na niemieckim rynku energii, osw.waw.pl (dostęp: 12.07.2016).

37 Stare elektrownie na węgiel kamienny są niekonkurencyjne. Właściciele wystąpili o likwidację 48 bloków o łącznej mocy 8 GW (stan na 20 października 2014). Jeśli niemiecki urząd regulacji energetyki (Bundesnetzagentur) uzna, że ich utrzymanie jest kluczowe dla zapewnienia stabilności systemu, może zobligować właścicieli do utrzymania elektrowni w ruchu.

38 Agencja ds. OZE, Netzausbau und internationaler Stromaustausch verringern Speicherbedarf, 16.01.2015, http://www.unendlich-viel-energie.de/netzausbau-und-internationalerstromaustausch-verringern (dostęp: 10.07.2016). 
i kamienny z łącznym udziałem na poziomie 43\%. Rozwój odnawialnych źródeł energii w Niemczech ma przyczynić się do ograniczenia importu węgla kamiennego. Duże nakłady finansowe przeznaczone na rozwój fotowoltaiki i farm wiatrowych spowodowały dynamiczny rozwój tych technologii w latach 2006-2010. Inwestycje w odnawialne źródła energii wzrosły w tym okresie ponad dwukrotnie. Średni koszt technologii w 2006 roku wynosił 4800 EUR/kW i spadł do wartości 1300 EUR/kW w 2013 roku, czyli prawie czterokrotnie.

Co warto podkreślić poziom mocy zainstalowanej nie jest równoznaczny z ilością wyprodukowanej energii elektrycznej. Fotowoltaika i wiatr mają podobne udziały w mocy zainstalowanej OZE. W 2013 roku produkcja energii $\mathrm{z}$ wiatru na lądzie była prawie dwukrotnie wyższa niż z paneli fotowoltaicznych. Wynika to z większej efektywności wykorzystania mocy w przypadku technologii wiatrowej. Biomasa, biogaz i woda łącznie, pomimo stosunkowo niewielkiego udziału mocy zainstalowanej OZE (ok. 13\%), produkują ponad $40 \%$ energii odnawialnej w Niemczech ${ }^{39}$. Produkcja energii z OZE w Niemczech jest zależna od warunków atmosferycznych, w przypadku części technologii wykazuje sezonowość. Jak wiemy panele fotowoltaiczne produkują energię głównie w miesiącach o dużym nasłonecznieniu, od marca do sierpnia. Elektrownie wiatrowe w miesiącach o dużej wietrzności - od grudnia do lutego. Prognozowanie produkcji energii z OZE na dany rok na podstawie danych nie daje pewnych wyników, szacunki operatorów są obarczone błędem prognozy. Brak możliwości dokładnego oszacowania produkcji OZE negatywnie wpływa na bezpieczeństwo energetyczne. Rozwiązaniem problemu sezonowości w produkcji OZE może być powiązanie elektrowni fotowoltaicznych i wiatrowych z geografią Niemiec. Duża liczba godzin słonecznych sprzyja rozwojowi fotowoltaiki na południu Niemiec. Duża gęstość zaludnienia na tym obszarze sprawia, że do rozbudowy paneli słonecznych można wykorzystać liczne powierzchnie dachowe. Między 2006 a 2013 rokiem zainwestowano w fotowoltaikę w Niemczech prawie 80 mld EUR ${ }^{40}$.

Wysoka wietrzność na północy Niemiec przyczynia się do szybkiego rozwoju mocy wiatrowych. W farmy wiatrowe zainwestowano prawie $30 \mathrm{mld}$ EUR, ich udział w produkcji energii elektrycznej w 2014 roku był prawie dwukrotnie większy niż fotowoltaiki. Ich budowa jest też wspierana przez znowelizowaną w 2014 roku ustawę o OZE.

39 J. Maćkowiak-Pandera, Reforma wsparcia OZE w Niemczech - ustawa EEG 3.0, gramwzielone.pl (dostęp: 13.06.2016).

40 W 2014 roku fotowoltaika zajęła dopiero trzecie miejsce pod względem udziału w całkowitej produkcji energii elektrycznej z OZE, po wietrze i biomasie. 
Do 2011 roku większość producentów OZE w Niemczech objęta była systemem FiT (Feed-in-Tariff, taryfa gwarantowana). Obecnie 60\% energii z OZE sprzedawane jest w systemie FiP (Feed-in-Premium), który zakłada sprzedaż bezpośrednią energii elektrycznej na giełdzie oraz wypłacanie premii producentom $\mathrm{OZE}^{41}$. Do 2019 roku w systemie FiP ma uczestniczyć nawet 80\% wszystkich producentów OZE. Nowy system wsparcia ma umożliwić Niemcom obniżenie kosztów rozbudowy energii odnawialnej, które dzisiaj ponoszone są głównie przez gospodarstwa domowe. Ważne dla dalszego rozwoju OZE jest to, że wraz z rozwojem energetyki odnawialnej wzrasta również całkowite obciążenie podatkami i opłatami odbiorców energii elektrycznej. Ceny energii elektrycznej dla gospodarstw domowych w Niemczech są jednymi z najwyższych w Europie (na koniec 2014 roku prawie 40\% wyższe niż średnia europejska). Największy wpływ na wzrost cen ma podnoszenie stawki opłaty OZE, która w latach 2006-2015 wzrosła o 600\%. Rozwój OZE wymaga wprowadzania nowych podatków i opłat pomagających zapewnić bezpieczeństwo systemu, tj. mechanizmy mocowe i usługi systemowe. 1 sierpnia 2014 roku weszła w życie nowelizacja niemieckiej ustawy o odnawialnych źródłach energii $(\mathrm{EEG})^{42}$, która w założeniu ma doprowadzić do obniżenia kosztów subsydiów energetyki odnawialnej poprzez obniżenie wsparcia dla najdroższych technologii. Nowelizacja określa ramy legislacyjne oraz wprowadza nowe zasady rozwoju OZE. Zmiany dotyczą głównie systemu wsparcia OZE, a także podmiotów objętych zwolnieniami z opłaty OZE. Ustawa określa również „korytarze rozwoju” poszczególnych technologii OZE, które pozwolą na osiągnięcie udziału OZE w zapotrzebowaniu na energię elektryczną do 2050 roku na poziomie $80 \%{ }^{43}$. Zgodnie z nowelizacją ustawy o OZE, wszystkie instalacje oddane do użytku po 1 sierpnia 2014 roku, o mocy zainstalowanej powyżej $500 \mathrm{~kW}$ podlegają obowiązkowi bezpośredniej sprzedaży energii elektrycznej na giełdzie. Od 2016 roku obowiązkiem tym objęte będą wszystkie urządzenia powyżej $100 \mathrm{~kW}$. Ponadto w 2014 roku wprowadzono opłaty na utrzymanie $\mathrm{w}$ rezerwie mocy przeznaczonych do

${ }^{41}$ Federalny Urząd Ochrony Środowiska, strona internetowa: https://www.umweltbundesamt.de/daten/energiebereitstellung-verbrauch/anteil-erneuerbarer-energien-amenergieverbrauch (dostęp: 13.06.2016).

42 Ustawa o odnawialnych źródłach energii (Gesetz für den Ausbau erneuerbarer Energien), art. 1 ust. 2.

43 Znowelizowana forma ustawy o OZE została zatwierdzona przez Komisję Europejską w kontekście przestrzegania zasad pomocy publicznej. Aby zapewnić zgodność w tym zakresie, nowelizacja z 2014 roku zakłada wprowadzenie od 2017 roku systemu aukcyjnego dla wsparcia wytwarzania energii ze źródeł odnawialnych. 
wyłączenia (głównie ze względu na wiek bądź nieefektywność). Utrzymanie odpowiedniej wartości rezerwy stanowi dodatkowy koszt dla konsumenta, ale jest konieczne przy niestabilnych dostawach prądu z OZE ${ }^{44}$. Wzrost kosztów energii elektrycznej wpływa na wzrost kosztów produkcji, a tym samym powoduje spadek konkurencyjności przemysłu.

Ostatnim zagadnieniem poruszanym w niniejszym opracowaniu jest kwestia zaopatrzenia niemieckiego rynku energetycznego w gaz. Niemcy są trzecim po Wielkiej Brytanii i Włoszech europejskim konsumentem tego surow$\mathrm{ca}^{45}$. W ciągu 25 lat zużycie znacznie wzrosło i w 2015 wyniosło $90 \mathrm{mld} \mathrm{m}^{3}$. Niestety kraj ten nie posiada własnych znaczących ilości paliwa gazowego, w 2010 roku z rodzimego wydobycia pochodziło 11\% zużycia tego nośnika (2008 roku - 14\%). Największym producentem gazu w Niemczech jest Dolna Saksonia, gdzie znajdują się najefektywniejsze złoża tego surowca. Niezbędny jest import gazu ziemnego, który wynosi 89\%. Największymi dostawcami tego paliwa są: Rosjanie, Norwedzy i Holendrzy ${ }^{46}$. Wspomniana już we wstępie wzorcowa dywersyfikacja, wynosząca po $20-30 \%$ z jednego kierunku, uniezależnia Niemców od różnych zawirowań na rynku gazowym ${ }^{47}$. W branży gazowniczej u naszego zachodniego sąsiada działa obecnie 750 przedsiębiorstw zajmujących się wydobyciem, przesyłem i dystrybucją tego nośnika energii do finalnych odbiorców. Duża liczba podmiotów przyczyniła się do znacznego rozwoju infrastruktury gazowniczej. Na terenie Niemiec funkcjonuje 380 tys. km gazociągów. Sieć gazowa składa się z ponad 100 tys. km gazociągów wysokiego ciśnienia, 150 tys. km rurociągów średniego ciśnienia ${ }^{48}$.

44 Ceny energii elektrycznej dla przemysłu wzrosły w 2014 roku w stosunku do 2010 roku o ok. $27 \%$, do poziomu $15,32 \mathrm{ct} / \mathrm{kWh}$.

45 T. Fornalczyk, Rynek energii w Niemczech, „Polska Energia” 2009, nr 1, s. 22-23.

46 Obecnie $90 \%$ zużywanego w Niemczech gazu pochodzi z importu. Głównych trzech dostawców - Rosja (36,4 mld $\mathrm{m}^{3}$ w 2014), Norwegia $\left(30,2 \mathrm{mld} \mathrm{m}^{3} \mathrm{w} 2014\right)$ i Holandia (26 mld $\mathrm{m}^{3} \mathrm{w} 2014$ ) - pokrywa ponad 95\% zagranicznych dostaw. W perspektywie najbliższych 15 lat do zera spadnie wydobycie krajowe oraz import z Holandii, a wzrośnie import z Rosji i Norwegii. R. Bujczuk, Zarządzanie zależnością. Uwarunkowania niemieckiej polityki gazowej, Raporty OSW, Warszawa 2016. Por też: E. Wyciszkiewicz, Geopolityka rurociagów. Współzależność energetyczna a stosunki międzypaństwowe na obszarze postsowieckim, PISM, Warszawa, 2008, s. 11.

47 Konsekwentna dbałość o różnorodność dostawców tego surowca występowała już w latach dziewięćdziesiątych, wówczas znaczny spadek importu z Holandii oraz zmniejszenie wydobycia z własnych złóż zrekompensowano dostawami z Norwegii.

48 Związek Operatorów Sieci Przesyłowych gazu (Vereinigung der Fernleitungsnetzbetreiber Gas e. V., FNB Gas), strona internetowa: http://www.fnb-gas.de/de/fernleitungsnetze/gastransport/gastransport.html (dostęp: 12.05.2016). 
Niemiecka strategia zapewnienia bezpieczeństwa w sektorze gazowym oparta została na trzech filarach: działaniach wewnętrznych, współpracy z Rosją oraz równoległym utrzymywaniu partnerskich stosunków z innymi krajami będącymi producentami gazu ziemnego. W ramach takiego modelu polityki energetycznej Niemcy skutecznie łączą cele niejednokrotnie sprzeczne i trudne do realizacji na poziomie Unii. Od początku XXI wieku w UE trwają procesy związane z budową jednolitego rynku gazu ziemnego. Ma on być rynkiem płynnym i liberalnym, na którym panować będą warunki pełnej konkurencyjności ${ }^{49}$. W tym kierunku zmierzały już regulacje tzw. drugiego pakietu energetycznego ${ }^{50}$. Przyjęty w 2008 zakłada on: ograniczenie o $20 \%$ emisji $\mathrm{CO}_{2}$ do 2020 roku w stosunku do poziomu z 1990 roku; poprawę efektywności wytwarzania energii elektrycznej w tym samym okresie o 20\%; zwiększenie o $20 \%$ produkcji energii elektrycznej pochodzącej z tzw. „czystych źródeł energii” ${ }^{1}$.

W tym samym czasie obliczono, że choć import gazu do 2020 roku zmniejszy się o 7,5\% w stosunku do 2010 roku, to import z Rosji wzrośnie blisko o $16 \%$ (z 47,4 $\mathrm{mld} \mathrm{m}^{3}$ do 55,1 $\mathrm{mld}^{3}$ ). Do 2043 roku spółki gazowe w Niemczech zakontraktowały dostawy gazu na łącznie $800 \mathrm{mld} \mathrm{m}^{3}$. Istotną częścią bezpieczeństwa energetycznego Niemiec jest infrastruktura transportowa, na którą składa się 55 tys. km gazociągu poza terytorium RFN oraz blisko 320 tys. wewnątrz landów ${ }^{52}$.

49 Liberalizacji rynku energetycznego nie towarzyszyło stworzenie odpowiedniej infrastruktury w całej Europie, dzięki której firmy mogłyby korzystać ze swoich nowo nabytych praw. W szczególności brak połączeń infrastrukturalnych pomiędzy narodowymi sieciami przesyłowymi gazu i elektryczności spowodował, że wolna konkurencja nie mogła w rzeczywistości zaistnieć. Skoro bowiem nośniki energii (przede wszystkim gaz) oraz elektryczność nie mogły być swobodnie przesyłane poza granice państw członkowskich, znaczenie zapisów pozwalających na dokonywanie takich operacji pozostało ograniczone.

50 Dyrektywa 2003/55/WE Parlamentu Europejskiego i Rady z dnia 26 czerwca 2003 r. dotycząca wspólnych zasad rynku wewnętrznego gazu ziemnego i uchylająca dyrektywę 98/30/WE (Dz. Urz. UE-sp. 12-2-211) (dalej: dyrektywa 2003/55/WE), oraz rozporządzenie nr 1775/2005 w sprawie warunków dostępu do sieci przesyłowych gazu ziemnego.

51 Pakiet ten znany jako 20x20x20 wywołał dyskusję nt. kosztów bezpieczeństwa energetycznego. Wielu ekspertów, polityków i dziennikarzy podnosiło argument, że pozbywając się energetyki opartej na węglu i atomie, jednocześnie uzależnia się Niemcy od dostawców gazu, głównie rosyjskiego.

52 M. Paszyn, Ekspansja Gazpromu na niemiecki rynek energetyczny w okresie rząów Angeli Merkel 2005-2015, „Przegląd Zachodni” 2015, t. 4. 
W 2005 roku Gazprom i Wintershall (spółka-córka koncernu BASF) razem $\mathrm{z}$ innym niemieckim koncernem E.ON Ruhrgas rozpoczęły realizację projektu Nord Stream. W 2008 roku podpisano umowę o powołaniu konsorcjum South Stream, w którym Gazprom ma ponad 50\% udziałów. W budowę gazociągu South Stream zaangażowany był Wintershall - 15\% udziału w projekcie. Podjęcie współpracy na niemieckim rynku energii konwencjonalnej jest korzystne zarówno dla koncernów niemieckich (E.ON, RWE, EnBW), jak i dostawców rosyjskich (Gazprom, Novatek) ${ }^{53}$. Najsilniej do współpracy $\mathrm{z}$ rosyjskimi dostawcami gazu dążył RWE, co wynikało przede wszystkim $\mathrm{z}$ tego, że ma on największe zadłużenie wśród niemieckich koncernów oraz poniósł straty na rezygnacji z energii jądrowej.

Innym elementem, który miał zapewnić Niemcom dostawy gazu było uczestnictwo niemieckich firm w projekcie budowy gazociągu Nabucco. Rozpoczęcie budowy mającego mieć ok. 3900 km długości gazociągu, było zaplanowane na koniec 2012 roku, jej zakończenie na koniec 2015 roku. Przepustowość miała wynieść $31 \mathrm{mld}^{3}$ surowca. Koszt konstrukcji planowano na około 7,9 miliardów euro i miał zostać pokryty w 30\% przez udziałowców, a w $70 \%$ z kredytów ${ }^{54}$. Do realizacji projektu budowy Nabucco powołano spółkę Nabucco Gas Pipeline International GmbH utworzoną w 2004 roku w Wiedniu. Udziałowcami w projekcie, obok niemieckiego RWE były: OMV (Austria), MOL z Węgier, rumuński Transgaz, Bulgargaz (Bułgaria), i BOTAŞ z Turcji. Wszyscy udziałowcy posiadali po 16,7\% akcji spółki. Zainteresowanie uczestnictwem w projekcie wyraziły także Gaz de France, niemieckie E.ON, rosyjski Gazprom. 13 lipca 2009 roku w Ankarze Turcja, Bułgaria, Rumunia, Węgry i Austria podpisały umowę w sprawie budowy magistrali, która miała mieć 3,3 tys. km długości, zaś jej przepustowość planowana była na 31 miliardów metrów sześciennych surowca rocznie. Jednak szybko okazało się, że rozbieżności pomiędzy udziałowcami były zbyt duże, co spowodowało wycofanie się RWE z tego projektu.

53 Rosyjskie koncerny, zarówno Gazprom, jak i Novatek dostrzegły we współpracy szansę na zwiększenie zysków na niemieckim rynku gazu, który się dynamicznie rozwija (produkcja, przesył, dystrybucja, elektroenergetyka). Koncerny niemieckie, ze względu na rosnące zadłużenie, dążą przede wszystkim do ograniczenia kosztów budowy nowych elektrowni konwencjonalnych zastępujących elektrownie jądrowe, wyprzedaży aktywów, m.in. z rynku gazu i dalszych renegocjacji długoterminowych kontraktów w celu zmniejszenia ceny surowca.

54 Projekt budowy Nabucco został włączony w program Trans-European Energy Network finansowany przez Unię Europejską. Ocena wykonalności projektu została opłacona z grantu Unii Europejskiej, zaś sam projekt został zaaprobowany w 2006 roku. 
Przykładem swoistej dywersyfikacji inwestycji na rynku gazowym była kolejna kooperacja niemiecko-rosyjska. 6 września 2011 roku na Forum Inwestycyjnym w Soczi rosyjski Gazprom, włoski ENI, francuski EdF i niemiecki Wintershall zawarły umowę o utworzeniu spółki South Stream Transport (SST) - przyszłego właściciela 900-kilometrowego morskiego odcinka gazociągu South Stream ${ }^{55}$. Podział akcji SST - Gazprom 50\%, ENI 20\%, EdF i Wintershall po 15\% - gwarantował rosyjskiemu koncernowi kontrolę nad projektem. Budowa 4-nitkowego gazociągu (o przepustowości ok. 15,6 mld $\mathrm{m}^{3}$ każda) miała się rozpocząć w 2013 roku, uruchomienie pierwszej nitki zaplanowano na rok 2015, a całej trasy - na 2018. Wstępnie szacowane koszty inwestycji to 15,5 mld USD $^{56}$. Jednak wydarzenia związane z aneksją przez Rosję Krymu i wojną w Donbasie, które zaowocowały sankcjami unijnymi, spowodowały załamanie tego projektu. W dniu 1 grudnia 2014 roku, podczas wizyty w Turcji prezydent Władimir Putin oświadczył, że ze względu na „niekonstruktywne stanowisko Komisji Europejskiej oraz bierność władz Bułgarii, Rosja jest zmuszona wstrzymać budowę gazociągu South Stream" ${ }^{\prime \prime}$.

Z kolei prezes Gazpromu Aleksiej Miller uznał projekt za zamknięty, nie przewidując możliwości jego reaktywacji ${ }^{58}$. Główną przyczyną decyzji Rosji są prawdopodobnie wynikające m.in. z sankcji problemy finansowe rosyjskiego koncernu, które uniemożliwiają realizację inwestycji ${ }^{59}$. Pochodną decyzji

55 The South Stream Gas Pipeline Through the Black Sea, http://www.south-stream-off shore.com/gas pipeline/project/ (dostęp: 10.06.2016).

56 Porozumienie udziałowców gazociagu South Stream, https://www.osw.waw.pl/pl/publikacje/analizy/2011-09-21/porozumienie-udzialowcow-gazociagu-south-stream (dostęp: 12.05.2016).

57 Sz. Kardaś, Niechciany gazociag: Rosja wstrzymuje budowe South Streamu, Analizy OSW, 03.12.2014; Putin rezygnuje z South Stream, http://www.rp.pl/artykul/ 1161571-Putin-rezygnuje-z-South-Stream.html (dostęp: 10.06.2016).

58 Przy okazji wizyty Putina, Gazprom i turecki Botas podpisały memorandum zapowiadające budowę nowego gazociągu przez Morze Czarne. Ma on umożliwić dostawy na rynek turecki, jak i do krajów południowej Europy. Prezydent Rosji zapowiedział, że Rosja będzie dynamiczniej rozwijać projekty LNG oraz zwiększać swój udział na pozaeuropejskich rynkach gazowych. Putin rezygnuje...

59 Koszty budowy odcinka morskiego wzrosły z 10 do 14 mld euro, a lądowego na terenie UE z 6 do 9,5 mld euro. Koszty budowy gazociągu zwiększyły się o blisko $40 \%$, ponieważ firmy uczestniczące w budowie, a objęte sankcjami, mają problemy z zaciąganiem kredytów inwestycyjnych. Zapewne na decyzję tę wpływ miało także stanowisko Komisji Europejskiej, kwestionującej zgodność z unijnym prawem umów zawartych przez Rosję z państwami, przez które miała przechodzić rosyjska 
Kremla o zaprzestaniu budowy South Streamu było anulowanie przez koncern BASF umowy z Gazpromem, dzięki której rosyjski partner zostałby jedynym akcjonariuszem Wingasu. W dniu 18 grudnia 2014 roku BASF ogłosił, że uzgodnił z Gazpromem anulowanie umowy o wymianie aktywów ${ }^{60}$.

Niewątpliwie wzmocnieniem pozycji Gazpromu w Niemczech było uruchomienia w dniu 8 października 2012 roku gazociągu Nord Stream - bezpośredniej trasy dostaw rosyjskiego gazu z Wyborga (Rosja) do Greifswaldu (Niemcy) przez Bałtyk. Dwie nitki magistrali osiągnęły tym samym docelową przepustowość $55 \mathrm{mld} \mathrm{m}^{3}$. Wzrost przepustowości Nord Streamu zwiększa możliwości Gazpromu manewrowania trasami przesyłu gazu i realizacji głównego celu tej inwestycji. Przy pewnych nakładach na rozszerzenie sieci przesyłowych na terenie Niemiec byłoby to technicznie możliwe. Sieć krajowych gazociągów połączonych z siecią Gazpromu, czyli JAGAL, MIDAL, STEGAL, WEDAL i Hamburg-Rehden, jest zarządzana przez Gascade Gastransport. Inwestycja ta pozwoliła Niemcom na zwiększenie własnego bezpieczeństwa energetycznego oraz wyeliminowała państwa, przez które dotychczas przebiegał tranzyt gazu ziemnego, a co za tym idzie wzmocniła geopolityczną pozycję Niemiec. W tym momencie Niemcy stały się czołowym partnerem Rosji w międzynarodowym handlu tym surowcem energetycznym.

Elementem bezpieczeństwa energetycznego jest nie tylko zachowanie dostaw wewnętrznych paliwa, ale i zabezpieczone zapasy surowca energetycznego w podziemnych zbiornikach (PMG). Na terenie Niemiec zlokalizowanych jest 47 takich magazynów. Dwadzieścia cztery usytuowane są w kawernach solnych o łącznej kubaturze wynoszącej 7,8 $\mathrm{mld} \mathrm{m}^{3}$. Największy magazyn znajduje się w miejscowości Rehden koło Bremy, jego pojemność równa jest

magistrala. Plan budowy South Streamu należał do jednego z najbardziej kosztownych projektów infrastrukturalnych Gazpromu. W grudniu 2012 roku koszt budowy rurociągu oszacowano na ok. 16 mld euro, natomiast w październiku 2014 roku ogłoszono, że miał być on wyższy o ponad $40 \%$.

60 A. Kublik, Gazprom nie przejmie niemieckiej firmy Wingas, http://wyborcza. pl/1,155287,17156054,Gazprom_nie_przejmie_niemieckiej_firmy_Wingas.html (dostęp: 10.06.2016). Na podstawie tej umowy rosyjski koncern miał przejąć od BASF kontrolny pakiet ponad 50\% akcji firmy gazowniczej Wingas, a w zamian Gazprom odstąpiłby niemieckiemu koncernowi pakiet akcji w spółce eksploatującej złoża gazu na Syberii „Żałujemy, ale transakcja wymiany aktywów nie zostanie sfinalizowana" - stwierdził szef koncernu BASF Kurt Bock w komunikacie cytowanym przez agencję TASS. Bock nie wyjaśnił powodów tej decyzji. Niemiecki dystrybutor gazu nie dla Gazpromu, https://www.forbes.pl/wiadomosci/niemiecki-dystrybutorgazu-nie-dla-gazpromu/t7hx55b (dostęp: 01.06.2016). 
$4200 \mathrm{mln} \mathrm{m}^{3}$. W budowie jest kolejnych 19 zbiorników o łącznej pojemności $7,4 \mathrm{mld} \mathrm{m}^{3}$. W sumie w niemieckich PMG zmagazynowane jest $20,3 \mathrm{mld} \mathrm{m}^{3}$ gazu ziemnego. Stanowi to największą rezerwę gazu w Unii Europejskiej i odpowiada ok. 25\% rocznego zużycia gazu ziemnego w Niemczech. Do największych przedsiębiorstw działających na rynku gazowym należą: E.ON - Ruhrgas AG, RWE, Wingas AG i VNG AG. Wielkość niemieckiego rynku paliwa gazowego powoduje, że wymienione podmioty znajdują się w czołówce największych firm gazowych na starym kontynencie zaangażowanych w budowę i eksploatację zarówno magazynów, jak i hubów gazu ${ }^{61}$.

W grudniu 2013 roku Gazprom podpisał umowę z niemiecką firmą Wintershall, firmą zależną od koncernu BASF, na mocy której rosyjska spółka przejąć miała gazociągi dystrybucyjne oraz magazyny gazu w Niemczech. Gazprom przejąć miał m.in. pełną kontrolę nad hubem gazowym w Rehden w okolicach Bremy. Magazyny te mają pojemności $4,4 \mathrm{mld} \mathrm{m}^{3}$. Ponadto rosyjski gigant miał otrzymać udziały w dwóch innych gazowych magazynach, w Jemgum w Dolnej Saksonii, oraz Haidach w Austrii (ten ostatni mimo swojej lokalizacji obsługuje głównie rynek niemiecki). Transakcja ta była uznana za klasyczną w modelu współpracy niemieckich koncernów z Rosjanami: wymiana udziałów w rynku unijnym za udziały w złożach surowca w Rosji. Wymiana ta miała podwójnie powiązać unijnego partnera z Rosją ${ }^{62}$. Przejęte przez Gazprom gazociągi i magazyny, wliczając te, które Gazprom już wcześniej kontrolował, uczynić miały z Niemiec pomost na rynki Francji, Holandii, Belgii, a w przyszłości Wielkiej Brytanii. Działania te wynikały ze strategii Gazpromu, który jest obecnie wyłącznym dostawcą gazu do rurociągów OPAL i NEL, tranzytowych magistral biegnących przez niemieckie terytorium, będących lądowymi odnogami Nord Streamu ${ }^{63}$. Rosyjski koncern jest też ich operatorem. Jak wiemy, głównym celem tego projektu ma być transport rosyjskiego surowca do krajów trzecich ${ }^{64}$.

61 Gabriel: Wir systematisieren die Energiewende und machen Energieeffizienz zur zweiten Säule, http://www.bmwi.de/DE/Themen/Energie/energiewende,did=672914. html (dostęp: 22.06.2016).

62 Dla Gazpromu była to transakcja, która miała przynieść mu znaczne korzyści w jego obecności na rynku UE, nie tylko w Niemczech. Niemcy były i są największym importerem rosyjskiego gazu w UE. Po tej transakcji miały być ważnym krajem tranzytowym.

63 Biorą one początek w Lubmin koło Greifswaldu, gdzie do niemieckiego lądu dociera Nord Stream. OPAL i NEL są lądowym przedłużeniem Gazociągu Północnego. OPAL biegnie na południe, równolegle do granicy z Polską, zaś NEL na zachód.

${ }^{64}$ W zamierzeniu udział Niemiec w projekcie Nord Stream jest jednym ze sposobów na dywersyfikację szlaków dostaw energii. Innym elementem polityki bezpieczeństwa 
Do zmiany niemieckiej polityki energetycznej mogło dojść dwa lata temu, gdy wiosną 2014 roku została zaproponowana przez ówczesnego premiera Polski, Donalda Tuska, unia energetyczna. Miała się ona opierać sześciu filarach. Pierwszy filar to infrastruktura energetyczna ${ }^{65}$. Drugim filarem miały być mechanizmy solidarnościowe ${ }^{66}$. Trzeci filar to zwiększenie siły przetargowej państw członkowskich i UE wobec dostawców zewnętrznych ${ }^{67}$. Czwartym filarem miał być rozwój rodzimych źródeł energii w $\mathrm{UE}^{68}$. W projekcie tym bardzo mało miejsca poświęcono energetyce odnawialnej, do której kraje takie jak Niemcy przywiązują ogromną wagę ${ }^{69}$. Piąty filar to dywersyfikacja dostaw energii do UE ${ }^{70}$. Szóstym filarem miało być wzmocnienie

w sektorze gazowym są aktywne poszukiwania alternatywnych do rosyjskich szlaków dostaw surowca między innymi w Norwegii, Afryce i na Bliskim Wschodzie. Czynności te prowadzić mają do zwiększenia znaczenia Niemiec w tranzycie i magazynowaniu importowanego gazu w Unii.

65 Chodziło o zwiększenie środków przeznaczonych na te projekty w unijnym budżecie oraz zwiększenie do 75\% unijnego finansowania niezbędnych inwestycji w krajach najbardziej uzależnionych od rosyjskiego gazu dostarczanego przez Gazprom.

W sytuacjach kryzysowych UE powinna wykorzystywać swoją skumulowaną siłę oddziaływania, by zapobiegać i reagować w sposób adekwatny do potencjalnych scenariuszy zakłócenia dostaw gazu. W sytuacji kryzysowej zadziałać powinny tzw. mechanizmy solidarnościowe i żadne państwo członkowskie nie powinno być pozostawione samo sobie, Oznaczałoby to jednocześnie konieczność znowelizowania tzw. rozporządzenia SOS (Security of Supply), które mówi o bezpieczeństwie dostaw energii i tworzy instrumenty, mające ograniczać skutki przerw w dostawach surowca w przyszłości.

67 Według projektu premiera Tuska, rola umów międzyrządowych miała być stopniowo redukowana do nieodzownych kwestii. Ponadto zwracano uwagę na zapewnienie przejrzystości działań kontrahentów. Wymieniono klauzule, które według projektodawcy powinny być zakazane zarówno w umowach dwustronnych, jak i w kontraktach między firmami. Należą do nich: klauzula take or pay, która zmusza do płacenia za zakontraktowaną ilość gazu niezależnie od tego, czy został odebrany, zakaz reeksportu, powiązanie cen gazu z cenami ropy czy ustanawianie punktów odbioru gazu wewnątrz UE, zamiast na granicy.

68 Polski rząd zaproponował wykorzystanie zasobów paliw kopalnych UE, w tym węgla i gazu łupkowego. Mowa także o przyznaniu darmowej puli uprawnień do emisji $\mathrm{CO}_{2}$ elektrowniom węglowym zapewniającym 15\% mocy krajowej, bądź o wsparciu finansowym dla technologii składowania $\mathrm{CO}_{2}$ pod ziemią (CCS).

69 Zdaniem Donalda Tuska, przyjęcie przez Polskę rozwiązań niemieckich, spowodowałoby, że już w 2017 roku nasz kraj musiałby dopłacić do odnawialnej energii 12 miliardów złotych. Ponadto, w dłuższej perspektywie takie rozwiązania mogłoby być szkodliwe, czy nawet zabójcze dla polskiej gospodarki.

70 Według pomysłodawcy, lepsza infrastruktura energetyczna w UE i bardziej zintegrowany wspólny rynek energii, pozwolą skutecznie przyciągnąć alternatywnych dostawców 
Wspólnoty Energetycznej poprzez zapewnienie bezpieczeństwa energetycznego sąsiadom Unii ${ }^{71}$.

Początkowo kanclerz Angela Merkel stwierdziła, że plany Tuska idą w dobrym kierunku, aczkolwiek plan ten wymaga dopracowania. Jednak według nieoficjalnego stanowiska Niemiec, ujawnionego 19 stycznia 2015 roku, Berlin zadeklarował co prawda poparcie dla projektu, ale główna część zamysłu premiera Tuska, czyli mechanizm wspólnego zakupu gazu, nie zyskał poparcia rządu niemieckiego. Według Berlina koordynacja zakupów gazu jest sprzeczna $z$ ideą zliberalizowanego europejskiego rynku. Zdaniem Niemiec, bezpieczeństwo dostaw gazu zostanie zagwarantowane dzięki zakończeniu budowy europejskiego rynku gazu oraz dzięki rozbudowie infrastruktury gazowej, czego ważnym elementem ma być dostęp do terminali $\mathrm{LNG}^{72}$. 9 marca 2015 roku przywódcy krajów UE poparli utworzenie unii energetycznej, według strategii zaproponowanej przez Komisję Europejską. Jednym $\mathrm{z}$ jej kluczowych założeń, jest zniesienie granic pomiędzy rynkami energii w 28 krajach członkowskich. Postanowiono, że unia energetyczna będzie opierać się na pięciu filarach: bezpieczeństwie energetycznym, solidarności i zaufaniu; zintegrowanym europejskim rynku energetycznym; efektywności energetycznej, przyczyniającej się do obniżenia zapotrzebowania na energię, dekarbonizacji gospodarki oraz na badaniach, innowacyjności i konkurencyjności. Sporną kwestią była przejrzystość umów na dostawy gazu ${ }^{73}$.

Pomimo deklarowanej unii energetycznej, większość krajów Wspólnoty została zaskoczona ogłoszeniem 4 września 2015 roku na Forum Ekonomicznym we Władywostoku informacji, że Gazprom podpisał dwa porozumienia z zachodnimi koncernami: umowę o rozbudowie gazociągu Nord Stream czyli budowę kolejnych nitek gazociągu, a także umowę o wymianie

zewnętrznych. Chodzi tutaj m.in. o przyciągnięcie dostawców gazu łupkowego z USA czy Australii. Według różnych szacunków, 10 państw Unii Europejskiej kupuje ponad połowę zużywanego przez siebie gazu ziemnego od rosyjskiego Gazpromu.

71 Ten filar bazuje na przekonaniu, że droga do bezpieczeństwa energetycznego Unii Europejskiej prowadzi przez stabilne i bezpieczne sąsiedztwo. Bezpieczni, pod względem energetycznym sąsiedzi to bezpieczniejsza UE.

72 Według berlińskich polityków, to właśnie zmniejszenie popytu na energię, dzięki wdrażaniu efektywności energetycznej, dekarbonizacja gospodarki to, obok rozwoju rynku wewnętrznego i infrastruktury, najważniejsze filary europejskiego bezpieczeństwa dostaw surowców energetycznych.

73 Szczyt zgodził się na zapis mówiący o zapewnieniu pełnej zgodności z prawem UE wszystkich porozumień związanych z zakupem gazu od zewnętrznych dostawców, zwłaszcza przez „wzmocnienie transparentności takich porozumień”. 
aktywów z koncernami niemieckim i austriackim OMV. W ich wyniku powstać mają dwa gazociągi przez Bałtyk z Rosji do Niemiec. Projekt Nord Stream 2 przewiduje budowę dwóch gazociągów morskich $\mathrm{z}$ roczną przepustowością $55 \mathrm{mld} \mathrm{m}^{3}$ gazu z Rosji do Niemiec przez Morze Bałtyckie - tyle samo, ile istniejący gazociąg Nord Stream. W ten sposób Nord Stream podwoi przepustowość dostaw przez Bałtyk do Zachodniej Europy. „Fakt, że w projekcie biorą udział globalne koncerny energetyczne, świadczy o jego ważności dla zapewnienia bezpieczeństwa i niezawodności dostaw gazu do europejskich konsumentów" powiedział prezes Gazpromu Aleksiej Miller ${ }^{74}$. Klaus Schäfer z zarządu E.ON stwierdził „Wraz z rozwojem projektu Nord Stream będziemy zabezpieczać przyszłe niezawodne dostawy gazu ziemnego do Niemiec i UE w perspektywie długoterminowej. Projekt ten wzmocni naszą współpracę z Gazpromem trwającą ponad 40 lat". Koszt budowy gazociągu ma wynieść 9,9 mld euro. Rurociągi mają być oddane do użytku do końca 2019 roku. Struktura finansowania nie jest ustalona. Realizacją projektu ma się zająć firma projektowa New European Pipeline AG, zarejestrowana w szwajcarskim Zug. W spółce tej Gazprom będzie miał 51\% udziałów, BASF/Wintershall, OMV, E.ON i Shell po 10\%, a Engie - 9\%. Konsekwencją podpisania przez niemieckie koncerny energetyczne umów z Gazpromem może być ograniczenie poparcia Niemiec dla działań UE dotyczących dywersyfikacji dostaw gazu do UE. Żaden ze znaczących niemieckich polityków nie skomentował doniesień o zawarciu tych. Świadczyć to może o tym, że rząd w Berlinie nie widzi przeciwwskazań dla rozbudowy Nord Streamu.

W ostatnich latach kanclerz Merkel i jej rządy nie zainicjowali żadnych projektów na rzecz dywersyfikacji dostaw gazu do Europy. Dzieje się tak pomimo składanych deklaracji o popieraniu takich inicjatyw jak np. unia energetyczna. Istnieje wyraźne ryzyko, że Berlin będzie skłonny do wsparcia niemieckich koncernów w realizacji ich projektów energetycznych prowadzonych wspólnie z koncernami kontrolowanymi przez władze w Moskwie. Druga umowa o wymianie aktywów Gazprom-BASF i Gazprom-OMV wpisuje się w widoczną od kilku lat współpracę części największych zachodnioeuropejskich firm gazowych (BASF, E.ON, ENGIE, Shell, OMV) z rosyjskim gigantem. Mało kto zwraca uwagę na to, że podpisane przez koncerny europejskie i Gazprom umowy są sprzeczne z celami prowadzonej przez UE polityki dotyczącej dywersyfikacji dostaw gazu ${ }^{75}$. W żaden sposób nie zwiększa

74 http://www.money.pl/gospodarka/wiadomosci/artykul/rozbudowa-nord-streamcoraz-blizej-jest,79,0,1895503.html (dostęp: 22.06.2016).

75 M. Paszyn, dz. cyt. 
to bezpieczeństwa energetycznego w Europie Środkowej oraz Południowo -Wschodniej. Osłabia to współpracę gazową krajów UE z Ukrainą, gdyż daje Rosji możliwość omijania terytorium ukraińskiego w procesie przesyłu na Zachód. Znamienne jest to, że Komisja Europejska nie zareagowała na podpisane porozumienia. Wiceprzewodniczący KE, komisarz ds. unii energetycznej Maroš Šefčovič zajął krytyczne stanowisko, jednak już komisarz ds. energii i klimatu Miguel A. Cañete stwierdził, że projekt nie rodzi problemów, jeśli tylko jest zgodny z unijnym prawem ${ }^{76}$.

Teoretycznie Energiewende może być początkiem „trzeciej rewolucji przemysłowej" w kierunku zielonej gospodarki i społeczeństwa opartego na zrównoważonym rozwoju. Konieczne jednak będzie ułożenie na nowo relacji państwo-społeczeństwo-gospodarka. Zgodnie z nowelizacją ustawy o OZE, udział energii odnawialnej w produkcji prądu ma systematycznie wzrastać - z obecnych ok. $20 \%$ do ok. $38 \%$ w 2020 roku. W 2030 roku ma on już wynieść około 50\%, w 2040 roku - 65\%, a w 2050 - aż 80\%. Konsekwencje Energiewende nie ograniczają się do sfery zaopatrzenia w energię. Spodziewać się można zmian $\mathrm{w}$ funkcjonowaniu nie tylko gospodarki, lecz także niemieckiego społeczeństwa i państwa. Likwidacja energetyki atomowej i znaczące ograniczenie węglowej spowodowało, że niemiecka gospodarka została uzależniona od dostaw gazu ziemnego. W efekcie dywersyfikacja dostaw i źródeł energii, która stanowiła o sile niemieckiej gospodarki, a szczególnie jej energetyki, może zostać osłabiona i okazać się przyczyną kryzysu i problemów najsilniejszej gospodarki UE.

Działania kolejnych rządów niemieckich, szczególnie po roku 2000, przyczyniły się do zmian infrastrukturalnych $\mathrm{w}$ gospodarce RFN. W chwili obecnej trudno jednak ocenić, czy działania te wzmocniły, czy też osłabiły gospodarkę naszych zachodnich sąsiadów. Wiemy jedno - wspieranie OZE, likwidacja energetyki atomowej i węglowej wiąże się ze znacznymi kosztami ponoszonymi zarówno przez firmy, jak i prywatnych odbiorców energii. Efekt opisywanych działań widoczny będzie dopiero za kilka dekad. W tym czasie dojść może do zmian w światowej gospodarce, które całkowicie zastąpią znany nam obraz przemysłu i energetyki. Chociaż nowy plan ma na celu poprawę

76 Sz. Kardaś, Gazowe business as usual? Nowe umowy Gazpromu z unijnymi koncernami, Analizy OSW, 16.09.2015, https://www.osw.waw.pl/pl/publikacje/analizy/2015-09-09/gazowe-business-usual-nowe-umowy-gazpromu-z-unijnymi-koncernami (dostęp: 20.07.2016); Szefczovicz: Rosja spuszcza z tonu ws. Nord Stream 2 ale przetestuje nas prawnie, http://biznesalert.pl/szefczovicz-rosja-spuszcza-z-tonu -ws-nord-stream-2-ale-przetestuje-nas-prawnie/ (dostęp: 20.07.2016). 
bezpieczeństwa energetycznego poprzez zmniejszenie importu surowców energetycznych, to jednak $\mathrm{w}$ chwili obecnej widoczne jest coraz większe uzależnienie niemieckiego rynku od rosyjskich dostawców, którzy równocześnie, za zgodą władz i firm niemieckich, są coraz bardziej obecni w energetyce tego kraju. Z punktu widzenia bezpieczeństwa energetycznego działania takie bynajmniej go nie zwiększają. Koszty zmian w energetyce, uzależnienie się od jednego, wiodącego dostawcy, nawet jeżeli jest ukryty pod kooperacją joint venture, wymiana aktywów firm energetycznych, powodują, że gospodarkę Niemiec czeka, najprawdopodobniej w ciągu kilku najbliższych lat, okres przewartościowań w zakresie bezpieczeństwa energetycznego.

\section{Zusammenfassung}

Die Gewährleistung stabiler und nachhaltiger Versorgung mit Brennstoffen ist das Ziel der Energiesicherheit in der Bundesrepublik. Um dieses Ziel zu erreichen, muss Deutschland die wirtschaftliche Berechnung und die Maßnahmen der Außenpolitik verwenden. Das Land intensiviert den Dialog und die Zusammenarbeit mit Unternehmen und Energieproduzierenden Ländern. Es unterstützt Projekte internationaler Firmen und Institutionen, um die Energiesicherheit in der Europäischen Union zu fördern. In den letzten zehn Jahren engagierte sich Deutschland in der Förderung der erneuerbaren Energien, die in den nächsten Jahrzehnten ein wesentlicher Bestandteil des Energiesystems werden.

\section{Bibliografia}

ANCYGIER A., Niemiecka polityka energetyczna: dwa kroki naprzód, jeden krok w tyt, Warszawa 2014.

BUJCZUK R., Zarzadzanie zależnością. Uwarunkowania niemieckiej polityki gazowej, Raporty OSW, Warszawa 2016.

ENVIRONMENT and Energy. Electricity Statistics - Provisional data for 2009, Eurostat, 2010.

FORNALCZYK T., Rynek energii w Niemczech, „Polska Energia” 2009, nr 1.

KARDAŚ Sz., Niechciany gazociag: Rosja wstrzymuje budowę South Streamu, Analizy OSW, 03.12.2014,

KUŹNIARSKI Ł., Energetyka jądrowa w Niemczech, Warszawa 2011.

LEWANDOWSKI A., KALISKI M., FRĄCZEK P., Rozwój energetyki jądrowej a bezpieczeństwo energetyczne, „Rynek Energii” 2012, nr 2.

LEWANDOWSKI A., ŻMIJEWSKI K., Wymiary energetycznego bezpieczeństwa, „Energetyka Cieplna i Zawodowa” 2007, nr 5. 
Polityka energetyczna Niemiec w latach 1990-2015. Próba bilansu 25-lecia

PASZYN M., Ekspansja Gazpromu na niemiecki rynek energetyczny w okresie rzadów Angeli Merkel 2005-2015, „Przegląd Zachodni” 2015, t. 4.

STEIVAN D., Energiepolitik. Wissenschaftliche und wirtschaftliche Grundlagen, Zürich 2007.

USTAWA o odnawialnych źródłach energii (Gesetz für den Ausbau erneuerbarer Energien), art. 1 ust. 2.

biznesalert.pl

bmwi.de

pap.pl

www.fnb-gas.de

www.money.pl

www.osw.waw.pl

www.south-stream-off shore.com

www.umweltbundesamt.de

www.unendlich-viel-energie.de

wyborcza.pl 